\title{
麴アミラーゼに就 て（第四報）
}

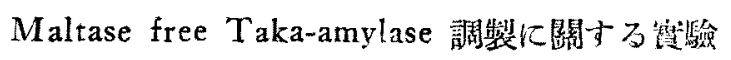

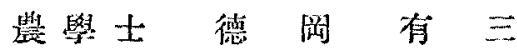

（制式會社 火合恒吉谪店） 昭和 11 年 9 月 24 日受理

Taka-amylase の研究特に酵素力學の研究に於て最方熏要なるは，醋素液に Maltase 孝含ま ぬこよである、從來の報告比よれば，Maltaseは不可分的とさ就てるる。從つてTaka-amylase

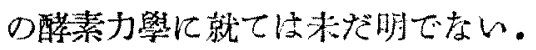

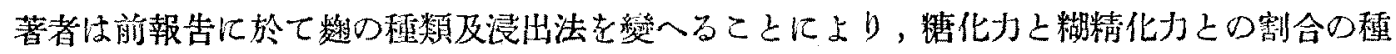
㮔異なる酵素液を得ることの可能なるを指摘した。本報告に於ては上記性質の異なる酵素液を 得可以は，Maltase 所水によつて容易に浸出し得るに反し，Amylase の過牛は水によつては

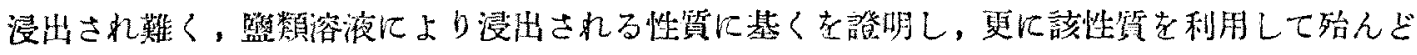
Maltase free の Taka-amylase 調製の可能孛る老報告したいと思ふ。

\section{Maltase free Taka-amylase 調製に關する實驗}

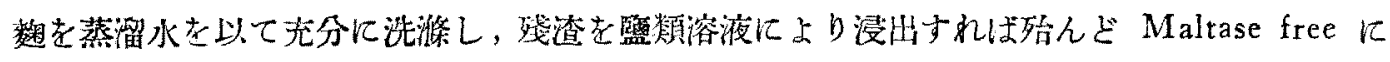

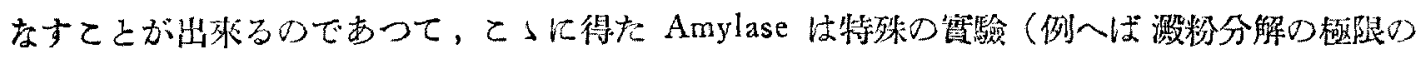

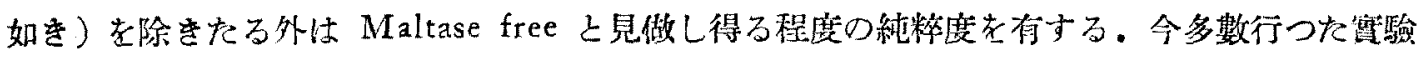
の內一，二の例に就て記戴する。

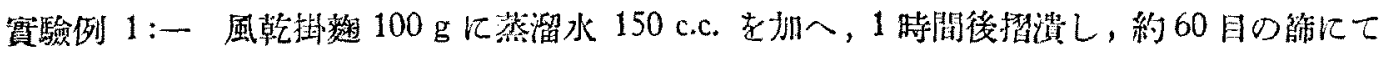

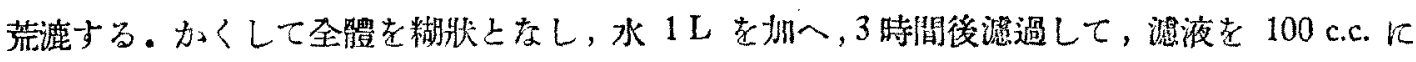

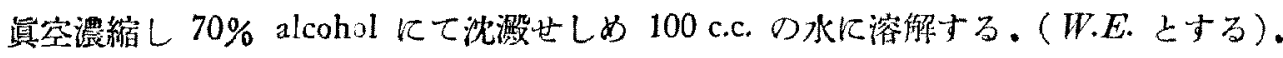

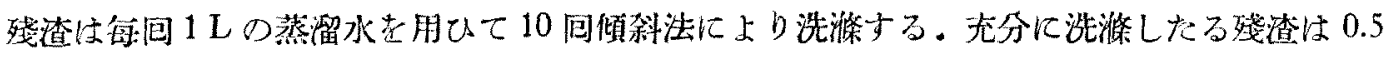

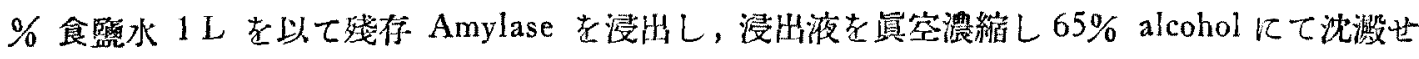
Lめ 100 c.c. D水に溶解する (S.E.R.I.).

察驗によるに alcohol 濃度 65\%以上に於ても多量に泌澱を得るが Amylase は含まない。

上に得た W.E. 及 S.E.R.I. に就て Maltase 及 Amylase 老檢するに次の如くである。

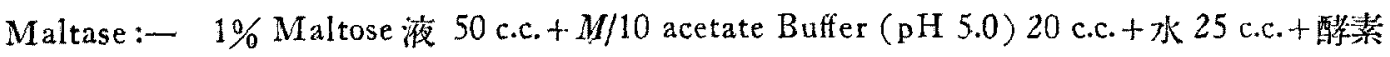

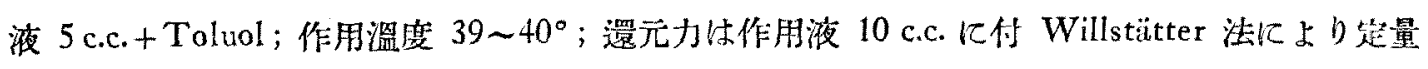

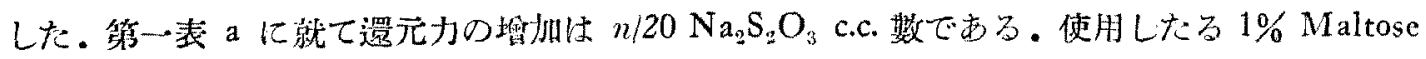
液 5 c.c. 快 $N / 20 \mathrm{Na}_{\mathrm{n}} \mathrm{S}_{2} \mathrm{O}_{3} 5.28$ c.c. に相监した。

Amylase : - 1\% 可塎性澱粉液 50 c.c. $+M / 10$, acetate Buffer (pH 5.0) 20 c.c. +水 29 c.c. +

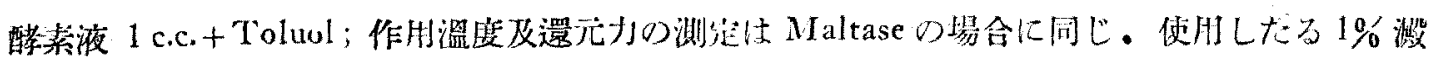


粉液 5 c.c. $=N / 20 \mathrm{Na}_{2} \mathrm{~S}_{2} \mathrm{O}_{3} 12.75$ c.c. (as Glucose) or 6.38 c.c. (as maltose).

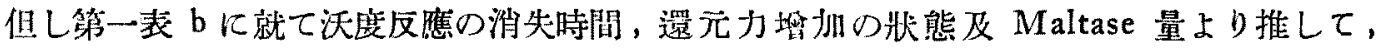
S.E.R.I. に於ては Maltose を生じ，W.E.は Glucose t生するものとして計算した。

第一表 a Maltose の分解

\begin{tabular}{|c|c|c|c|c|c|c|}
\hline \multirow{2}{*}{$\begin{array}{c}\text { 作用时間 } \\
\text { (分) }\end{array}$} & \multicolumn{2}{|c|}{10 c.c. 中還元力の增加 } & \multicolumn{2}{|c|}{ Maltose 分解题 } & \multicolumn{2}{|c|}{$\mathrm{K} \times 10^{5}$} \\
\hline & $W . R$. & S.E.R.I & W.E. & S.E.R.R. & W.E. & S.E.R.I \\
\hline 30 & 1.18 & 0 & 22.3 & 0 & * 366 & - \\
\hline 60 & 1.95 & 0 & 36.9 & 0 & * 334 & $\longrightarrow$ \\
\hline 180 & 3.80 & 0 & 72.0 & 0 & * 307 & - \\
\hline 420 & 4.15 & trace & 78.6 & trace & 160 & - \\
\hline 1440 & 5.03 & 0.60 & 95.2 & 11.4 & 147 & 3.7 \\
\hline
\end{tabular}

第一表 b 溉 粉の分解

\begin{tabular}{|c|c|c|c|c|c|c|c|}
\hline \multirow{2}{*}{$\begin{array}{c}\text { 作用時間 } \\
\text { (分) }\end{array}$} & \multicolumn{2}{|c|}{10 c.c. 中還元力 } & \multicolumn{2}{|c|}{$\begin{array}{c}\text { 溉汾分解量 } \\
(\%)\end{array}$} & \multicolumn{2}{|c|}{$\mathrm{K} \times 10^{5}$} & \multirow{2}{*}{$\begin{array}{l}\text { 沃度反醀 } \\
\text { 消失時間 }\end{array}$} \\
\hline & $W . E$. & S.E.R.I. & W.E. & S.E.R.I. & W.E. & S.E.R.I. & \\
\hline 15 & 0.92 & 0.77 & 7.2 & 12.1 & 217 & * 372 & $W . E .=90$ 分 \\
\hline 30 & 1.90 & 1.50 & 14.8 & 23.5 & $* 234$ & * 388 & S.E.R.I. $=46$ 分 \\
\hline 60 & 3.60 & 2.40 & 28.2 & 37.6 & $* 240$ & 342 & \\
\hline 120 & 5.90 & 3.13 & 46.3 & 49.1 & 225 & 244 & \\
\hline 300 & 8.15 & 3.70 & 64.0 & 57.9 & 148 & 126 & \\
\hline 1440 & 10.20 & 4.15 & 80.0 & 65.0 & 49 & 32 & \\
\hline 2880 & 10.88 & 4.62 & 85.3 & 72.4 & $29^{\circ}$ & 19 & \\
\hline
\end{tabular}

上表に就て W.E. と S.E.R.I. との間には著しい相造が你在し，*印の $\mathrm{K}$ 在平均して此較 すれば W.E. は S.E.R.I. に對L 142 倍の Maltase 老含むてと索知る。

以上の方法に上つてはMaltaseは其以上除くことが禹來なかつた。而して此方法によるAmy-

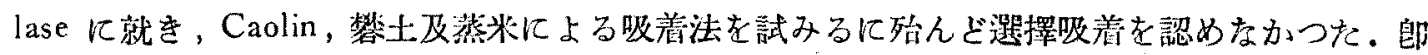

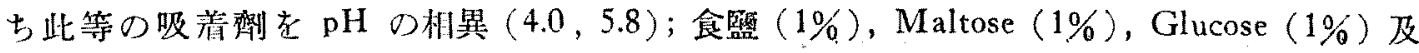

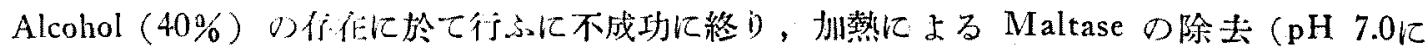

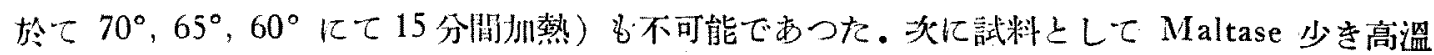
数圭用ひた。

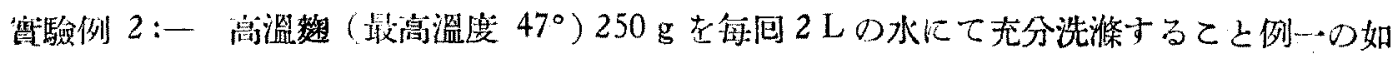

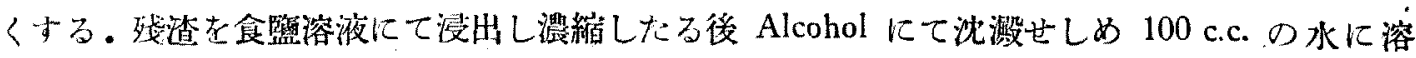
解した。(S.E.R.II.)

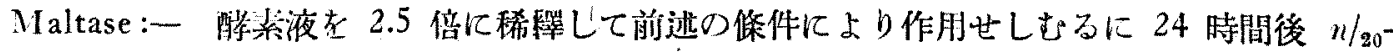
$\mathrm{Na}_{2} \mathrm{~S}_{2} \mathrm{O}_{3} 1.5$ c.c. を消損した。Amylase 量は沃应反應消失時間に逆比例するものとすれば， 
Maltase 含量を S.E.R.I.と比較するに $\frac{15}{6} \times \frac{5}{2} \times \frac{7}{46}=0.95$ となり殆んど Amylaseに對する Maltase 量は等しh.

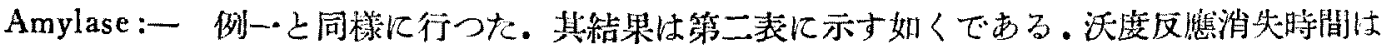

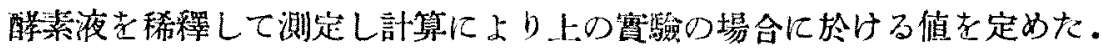

以上の凟驗結果を圖示すねば第一圖の如くである。

第二表 S.E.R.II. K依る澱粉の分能

\begin{tabular}{|c|c|c|c|c|}
\hline $\begin{array}{c}\text { 作用時間 } \\
\text { (分) }\end{array}$ & 10 c.c. 中邆元力 & $\begin{array}{c}\text { 澌妢分解量 } \\
(\% 0)\end{array}$ & $\mathrm{K} \times 10^{5}$ & 沃度反膲消失時間 \\
\hline 15 & 2.95 & 46.2 & 1797 & 7 分 \\
\hline 30 & 3.50 & 54.9 & 1151 & \\
\hline 60 & 3.90 & 61.1 & 684 & \\
\hline 180 & 4.20 & 65.8 & 259 & \\
\hline 360 & 4.60 & 72.1 & 154 & \\
\hline 1440 & 5.90 & 92.5 & 173 & \\
\hline
\end{tabular}

第

圖

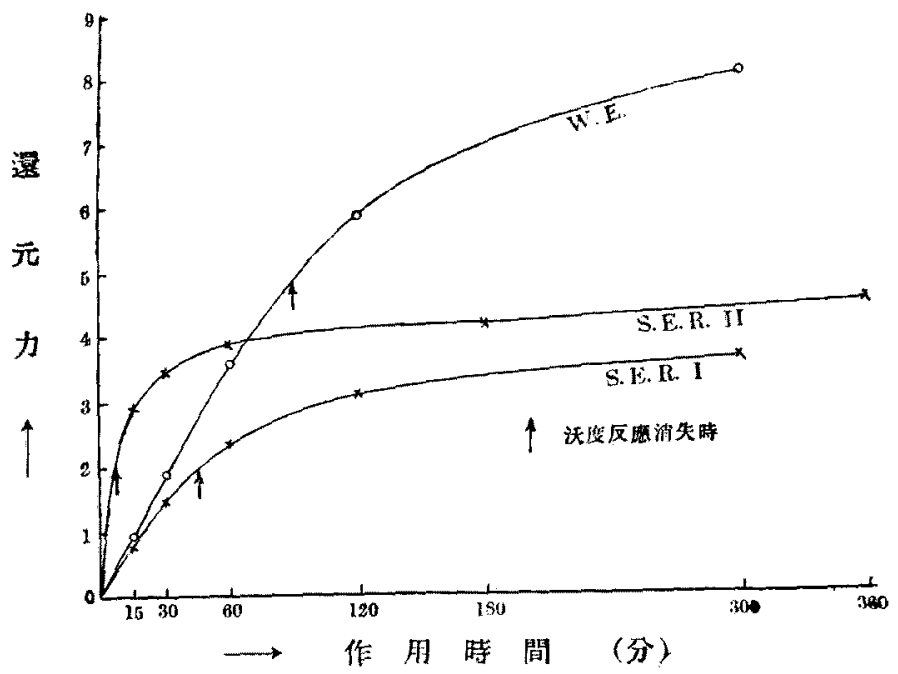

Taka-amylase による生成糖類に就て

從來 Taka-amylase に上る澱粉分解に於ては定量的に Glucose に分解するもの之見做され てるる、而して如上の假定の誤なるてと注第三報に於て著者の報告せし如く，糊精化力との此 が種その階程に於て異る酵素液を得るととに上り明白である。又 Taka-diastaseより Maltase ○分離は不可能とされてるるにより，果して Taka-amylase に上つては他の Amylase 》如く Maltose t生し，份在する Maltase に上りGlucose 几分解されるものなりや，或は直接的に Glucose に迄分解するかに就てすら明瞭に證肠されてるない。

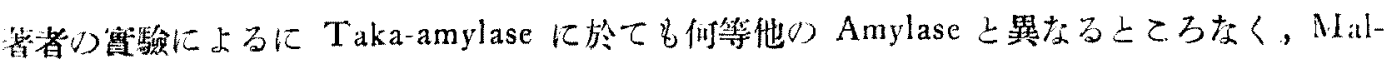


tose を生じ，混在する Maltaseにより Glucose に分解するるのであるととを指摘し得を。 其證左を列舉れば炏の如くである。

（1）W.E. 及 S.E.R. に就て比較するに，沃度反應汾失時に於ける澱粉分解量は前者古 Glucose とし，後者を Maltose とすれば殆んど一致する。

（2）W.E.による上きは作用液の還元かが Maltose と假定したる點を短時間に超過するに 反し，S.E.R.によつてはS.E.R.II. の如き强力なるものに於ても容易に超過しない。

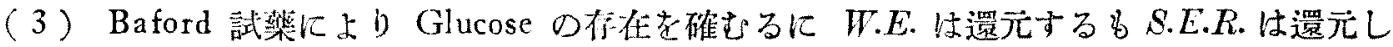
ない。

（4）Osazone を生成出し屯るに，W.E. は加熱時に於て多量の沈澱を生じ，檢鏡するに

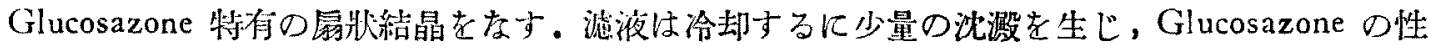

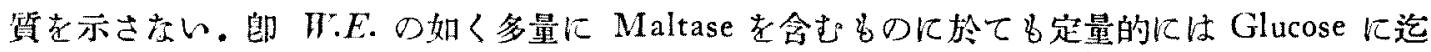

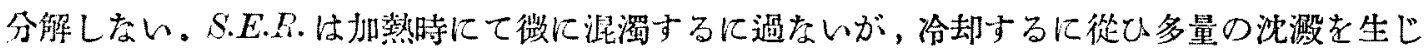

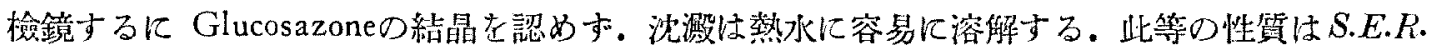
によつては殆んど Glucose を生じないてとは明白であつて，Maltose 吉生ずるものと思惟し得 る.（(3), (4) は24 時間後り作用液に就き實驗した)。

總括

（1）Koji-Maltaseは水に上り容易に浸出し得るも，Amylaseの過牛浸出されない。漖者 は該性質を利用して殆んも゙ Maltase free のTaka-amylase 及 Maltase を著しく多量に含む

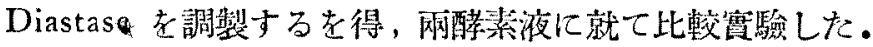

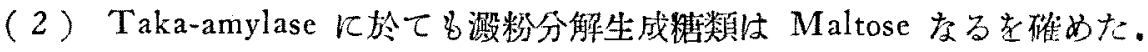

本報告に際し終始御筤篤なる御助言亚に御校閣を晹はつた片桐先生に重好て深謝致します。

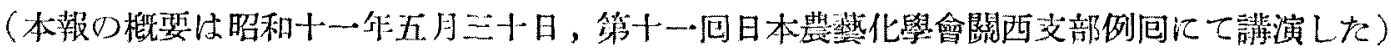

